\title{
Critical Review of Indonesian Government Legal Policies on The Conversion of Protected Forests and Communal Lands of The Indigenous Batak People around Lake Toba
}

\author{
Imamulhadi $^{*}$ Nia Kurniati** \\ DOI: https://doi.org/10.22304/pjih.v6n3.a2
}

Submitted: September 30, 2019 | Accepted: December 05, 2019

\begin{abstract}
The Development Plan of Sibisa Lake Toba Tourism Area as The National Strategic Area for Tourism by performing a land conversion on protected forests and communal lands had stirred up a problem dilemma regarding the resistance from indigenous people around Toba Lake. It is crucial to be questioned, whether the conversion policy of protected forests and communal lands by the Indonesian Government to develop Sibisa Danau Toba Tourism Area is in accordance with related laws and regulations? As the answer, it can be concluded that the mentioned policy opposes: Article 18b of the 1945 Constitution; Article 15 of the Law of 2009 Number 32 on Environmental Protection and Management; Presidential Regulation Number 81 of 2014 on The Spatial Planning of Lake Toba Area; The Law of 1999 Number 39 on Human Rights; The Law of 2016 Number 6 on Village Government, and lastly, the United Nation Declaration on Human Rights of Indigenous People (UNDHRIP).
\end{abstract}

Keywords: Communal Rights, Indigenous People, Land Conversion

\section{Telaah Kritis atas Kebijakan Hukum Pemerintah Indonesia terkait Alih Fungsi Hutan Lindung dan Tanah Ulayat Masyarakat Adat Batak di sekitar Danau Toba}

\begin{abstract}
Abstrak
Rencana Pembangunan Kawasan Pariwisata Sibisa Danau Toba sebagai Kawasan Strategis Nasional Kepariwisataan dengan melakukan alih fungsi hutan lindung dan tanah ulayat telah menimbulkan permasalahan yang dilematis karena mendapat perlawanan dari masyarakat adat di sekitar Danau Toba. Terhadap kebijakan tersebut penting untuk dipertanyakan apakah kebijakan alih fungsi hutan dan tanah ulayat oleh Pemerintah Indonesia untuk pembangunan Kawasan Pariwisata Sibisa Danau Toba telah sesuai dengan peraturan perundang-undangan yang terkait? Sebagai jawaban atas permasalahan, penulis menyimpulkan bahwa kebijakan telah bertentangan dengan: Pasal $18 b$ UUD 1945; Pasal 15 Undang-Undang Nomor 32 Tahun 2009 tentang Perlindungan dan Pengelolaan Lingkungan Hidup; Peraturan Presiden Nomor 81 Tahun 2014 tentang Rencana Tata Ruang Kawasan Danau Toba; Undang-Undang Nomor 39 Tahun 1999 tentang Hak Asasi Manusia; Undang-

PADJADJARAN Journal of Law Volume 6 Number 3 Year 2019 [ISSN 2460-1543] [e-ISSN 2442-9325] Lecturer of the Faculty of Law of Universitas Padjadjaran, Jl. Dipatiukur No. 35 Bandung, S.H (Universitas Padjadjaran), M.H (Universitas Padjadjaran), Dr. (Universitas Padjadjaran), Email: imamulhadi@unpad.ac.id

** Lecturer of the Faculty of Law of Universitas Padjadjaran, J. Dipatiukur No. 35 Bandung, S.H. (Universitas Padjadjaran), M.H. (Universitas Padjadjaran), Dr. (Universitas Padjadjaran), Email: nia_widiawan@yahoo.com
\end{abstract}


Undang Nomor 6 Tahun 2016 tentang Pemerintahan Desa, dan bertentangan dengan United Nations Declaration on Human Rights of Indigenous Peoples (UNDHRIP)

Kata Kunci: Alih Fungsi Lahan, Hak Ulayat, Masyarakat Hukum Adat

\section{A. Introduction}

The Indonesian government is currently in the process of developing the tourism sector in order to increase national foreign exchange from outside the oil and gas and palm oil sectors. Related to this, the Indonesian government has adopted a strategic policy in a development program called "National Strategic Area for Tourism". The program is planned to develop Bali-class tourist areas, and one of the tourist areas that is expected to match Bali is Lake Toba tourism in the province of North Sumatra. In realizing the development of the Sibisa Lake Toba Tourism Area, the Indonesian Government has formed a Management Agency that was formed based on the Presidential Regulation of the Republic of Indonesia Number 49 of 2016. Through this Presidential Regulation, the Management Agency is given the right to manage a land area of at least 500 hectares that crosses Pardamean Sibisa Village, Motung Village, and Sigapiton Village of Ajibata District, Toba Samosir Regency, North Sumatra Province. ${ }^{1}$

Based on the previous government policy, regarding the management area of at least 500 hectares for the development of the Sibisa Lake Toba Tourism Area, the management land intended for the Management Agency has been designated as a protected forest area. The status of protected forest is certainly an obstacle to the development of the Sibisa Lake Toba Tourism Area. To overcome this, the Management Agency then proposes to perform a land conversion on the forest.

As a follow-up to the proposed land conversion on the forest, the Minister of Environment and Forestry of the Republic of Indonesia has converted the area from protected area (protected forest) into cultivation area (production forest). The stipulation lies on the Decree of the Minister of Environment and Forestry Number 155/MENLHK/SETJEN/PLA.2/3/2017 on Land Conversion between the Main Functions of Forest Areas from Parts of Sibisa Protected Forest Areas to convert able Production Forest Areas in Toba Samosir Regency, North Sumatra Province. It covers at least 386.50 hectares. In addition, on February 15 2018, the Minister also has issued a Decree Number SK.92/MENLHK/SETJEN/PLA.2/2/2018 on the Release of a Convertible Production Forest Area on behalf of the Governor of North Sumatra for the Development of the Lake Toba Tourism Area located in Toba Samosir Regency, covering \pm 386.50 hectares.

However, the legal problems faced in the efforts of developing the Sibisa Lake Toba Tourism Area were not resolved until the land conversion of the forest area

Presidential Regulation Number 49 of 2016 on Authority Management Agency of Lake Toba Area 
from protected forest area to production forest area was determined. The 500hectare area of the Management Agency turned out to be overlapping with the 121-hectares of communal forest and communal land of the indigenous peoples of the Raja Bius Motung, 28 hectares of the Sirait Pardamean Sibisa clan, and 120 hectares of the indigenous peoples of Bius Raja Naopat Sigapiton and the ButarButar Sigapiton clan. ${ }^{2}$

Addressing the above issues, the researcher considers it important to criticize government policies, whether the policies are appropriate and fair in the context of Indonesia as a state of law. For that reason, it is interesting to question whether the policy of the land conversion of forests and communal lands by the Indonesian Government for the development of the Sibisa Lake Toba Tourism Area is in accordance with the relevant laws and regulations. And what is the ideal solution to the land dispute between the Indonesian Government and the Indigenous People? The discussion of these issues aims to provide a solution to the policy dilemma of the land conversion of protected forest for the benefit of the development of Lake Toba tourism area that overlaps with communal forests and communal rights of some indigenous peoples around Lake Toba.

\section{B. Environmental Protection and Spatial Planning}

The law of environmental and spatial planning recognizes the principle of "spatial use in accordance with function and designation". ${ }^{3}$ Space, based on support capacity, carrying capacity, and resilience, has certain functions. Based on its function, space is conceptually divided into protected space and cultivation space. The protected space's main function is for environmental preservation, and the cultivation space, based on the condition and potential of natural resources, human resources, and artificial resources is to be utilized for the maximum benefit of the people's welfare. Guided by these principles, the use of space really must pay close attention to the support capacity, carrying capacity, and resilience of the space itself. Soil with a support capacity that leads to fertile soils such as latosol ${ }^{4}$ type of land is suitable for agriculture. Regosol, lithosol, organosol, and renzina soils as erosion-sensitive soils are ideal for protected areas. Forest areas that have a slope of at least $40 \%$ are ideal for protected forests. Forest areas that have a minimum height of 2000 meters above sea level are ideal for protected forest areas. In addition, slopes with steep levels are ideal for protected areas.

Guided by support capacity, carrying capacity, and resilience, the Presidential Regulation of the Republic of Indonesia Number 81 of 2014 on the Spatial Planning

\footnotetext{
Violeta Simatupang, et al., "Legalitas Klaim Hak Atas Tanah Ulayat Marga-marga di Sekitar Lahan BOPDT," Legal Opinion, Bandung, 2018. p. iii.

3 See the Law of 2009 Number 32 on Protection and Management of Environment, and the Law of 2007 Number 26 on Spatial Planning

4 Flysh Geosh "Mengenal Jenis Jenis Tanah di Indonesia: Latosol, Regosol, dan Andosol" https://www.geologinesia.com/2017/07/mengenal-jenis-jenis-tanah-di-indonesia.html, accessed on November 2018.
} 
of Lake Toba Areas has now been enacted. In the Presidential Regulation, it is regulated that the purpose of the Lake Toba Area spatial planning is to realize the Lake Toba Area as the water of life for the community (aek natio), ecosystems, village areas of indigenous peoples of Batak, and the development of a world-scale tourism area. To realize this goal, the Presidential Regulation of the Republic of Indonesia Number 81 of 2014 on the Spatial Planning of Lake Toba Area establishes 8 (eight) policies related to the spatial planning of the Lake Toba Area, including ${ }^{5}$

1) maintenance of the stability of the quantity and quality of Lake Toba water;

2) preservation of important ecosystems of the lake and surrounding waters;

3) preservation of the village area and the culture of the indigenous people of Batak;

4) development and control of the use of high-end tourism areas that are adaptive to natural disasters;

5) control of lake fisheries cultivation areas;

6) maintenance of the area of agricultural food crops for food security;

7) control of the area of animal husbandry, horticulture, and community-based plantations that are environmentally friendly;

8) realization of cooperation in the management and maintenance of environmental quality, marketing the production of cultivation areas and improving inter-regional infrastructure and facilities services.

Related to the spatial structure plan, the Presidential Regulation of the Republic of Indonesia Number 81 of 2014 on the Spatial Planning of Lake Toba Areas stipulates that the purpose of the Lake Toba Area spatial structure plan is to support the Lake Toba Area as an excellent tourism area. Also related to the spatial plan, it is regulated that the Lake Toba Area Spatial Plan aims to optimize the use of space for the preservation of water quality and quantity, ecosystems, indigenous peoples' villages, and the development of a tourism area that consists of a designation of protected areas and cultivation areas. Protected areas are classified into protected zones that (1) provide protection to their subordinate areas (protected forest areas and water catchment areas); (2) is a local protected area (river border and lake area); (3) is a nature reserve, nature preservation, and cultural preservation area; (4) is a natural disaster-prone area; and (5) is a geological protected area. ${ }^{6}$

The Presidential Regulation Number 81 of 2014 on the Spatial Planning of Lake Toba Area regulates that Ajibata District, Toba Samosir Regency is included in the protected zone of protected forest area, protected zone of the water catchment area, protected zone of the groundwater basin, and included in the protected zone

Presidential Regulation Number 81 of 2014 on the Spatial Planning of Lake Toba Area Ibid. 
of the area around the lake. This shows that Ajibata District is included in a protection zone that provides protection to the subordinating areas, and is included in the local protection zone.

Before the establishment of the Ajibata District as the Sibisa Lake Toba Tourism Development Zone, since 1982 based on the Decree of the Minister of Agriculture Number 923/KPTS/UM/ 12/1982 dated December 27, 1982 on the Appointment of Forest Areas in the Region of North Sumatra 1, most of the Ajibata District is protected forest. The status of protected forest as stipulated through the Decree of the Minister of Agriculture Number 923 of 1982. When associated with the Presidential Regulation Number 81 of 2014 on the Spatial Planning of Lake Toba Area, it is ideal, because the support capacity of most of the Ajibata District area is directed to the protection function. Ajibata District is one of the districts located on the edge of Lake Toba. The topographical condition of the Ajibata District, which is located on the edge of Lake Toba, is almost entirely in the form of steep cliffs. The hydrological state of the Ajibata District is entirely in the Basin of Asahan Toba River. There are rivers and creeks as a buffer for ecosystem life. Ajibata District is also a region of Groundwater Basin. ${ }^{7}$

In line with the Presidential Regulation Number 81 of 2014 on the Spatial Planning of Lake Toba Area, it is planned to develop the Sibisa Lake Toba Tourism Area covering 368.5 hectares in the area of the Ajibata District. However, unfortunately according to the Amdal (Environmental Impact Analysis), the business plan that will be built and developed includes the 500-capacity Tourism Academy, Training Centers, Hypermarkets and Cinemas, Shop Houses and Karaoke, Shopping and Souvenir Areas, Exclusive Cliff Resort Hotels, Lake View Residential Villas, Relaxation Areas and SPA, Bars and Restaurants, Golf Courses, MICE, Flower Gardens, and Hospitals. ${ }^{8}$

As already stated, it is mandatory in the utilization of space to implement the principle of space utilization according to function and designation. Based on the results of research conducted by the North Sumatra Provincial Forestry Service and the Integrated Team, it is known that the support capacity and carrying capacity of the area in the Ajibata District leads to the protection function. In general, there is only a small number of existing support capacity and carrying capacity of the area in Ajibata District that leads to the cultivation function. More than $40 \%$ of the area in Ajibata Subdistrict is topographically steep. ${ }^{9}$ With this topographic condition, the main function of the area in Ajibata District should be for protection. In addition to the topography, the fact that in general directs the area in Ajibata District to function as protection is the hydrological state as a River Basin, and Groundwater Basin, and the erosion-prone soil conditions. ${ }^{10}$ Due to such conditions, the policy of

\footnotetext{
See the Office of Forestry, op.cit. pp. 19-21.

See Amdal of the Development of Tourism Site SIBISA.

See the Office of Forestry, loc.cit.

Ibid.
} 
establishing Ajibata District as the Sibisa Lake Toba Tourism Development Zone is very important to evaluate, because it has the potential to pollute and damage Lake Toba's ecosystem. For this reason, the Presidential Regulation of the Republic of Indonesia Number 49 of 2016, which stipulates that the development of the Lake Toba Tourism Area take place in Ajibata District, is strongly revised. The revision is intended to provide the opportunity to divert the location of the Sibisa Lake Toba Tourism Area Development from Ajibata District. Most of the area in Ajibata District must be returned to its original function as protection. The policy that defines the majority of the area in Ajibata District as protected forest must be maintained by revoking or canceling the Decree of the Minister of Environment and Forestry Number 155/MENLHK/SETJEN/PLA.2/3/2017 on Land Conversion Between Main Functions of Forest Areas from Parts of Sibisa Protected Forest Areas to Convertible Production Forest Areas in Toba Samosir District, North Sumatra Province. The area covers about 386.50 hectares (Ministry of Environment Decree Number 155 of 1982 on Transfer of Protection Forest Function).

Some basic reasons that can be used as legal considerations of revocation or cancellation of the Decree of the Ministry of Environment and Forestry Number 155 of 2017 on Land Conversion of Protected Forest among others are that the decree has not met the requirements because the policy on the conversion of protected forest has not been based on the recommendations of the (KLHS) as required by Article 15b Paragraph (2) of the Law Number 32 of 2009 on Environmental Protection and Management (UUPPLH 2009). It reads "The Government and Regional Governments must make Strategic Environmental Assessment to ensure that the principle of sustainable development has become the basis and integrated in the development of an area and/or policies, plans, and/or programs." ${ }^{11}$ Revocation and cancellation can also be based on the reason that the Decree of the Ministry of Environment and Forestry Number 155 of 2017 on Land Conversion of Protected Forest. It is not in line with the Presidential Regulation Number 81 of 2014 on the Spatial Planning of Lake Toba Area, which has included Ajibata District into the protection zone. Because Ajibata District is included in the protected zone, the land conversion of protected forest in Ajibata District is difficult to justify. Based on these things, it can be concluded that the Decree of the Ministry of Environment and Forestry Number 155 of 2017 on Land Conversion of Protected Forest should be suspected to have legal defects.

\section{Protection of Indigenous Peoples}

11 The Law Number 32 of 2009 on Environmental Protection and Management 
Article 18b, Paragraph (2) of the 1945 Constitution states that "the State recognizes and respects the unity of indigenous peoples and their traditional rights as long as they are still alive and in accordance with the development of society and the principles of the Unitary State of the Republic of Indonesia, which are regulated in the law". The background to the formulation of Article 18b paragraph (2) in the Indonesian Constitution is that Indonesia has a diversity of cultures, customs, along with a diversity of laws. Since the days of our ancestors until now, there are still many indigenous peoples in Indonesia. One of them that still survive to this day is the indigenous people of Batak.

Article 18b paragraph (2) of the 1945 Constitution requires that law regulate all matters concerning the unity of indigenous peoples and their traditional rights. The law that specifically regulates indigenous peoples and their traditional rights is still at the draft stage at the level of the Indonesian House of Representatives as the initiative holder. However, in the context of filling the legal vacuum, regarding indigenous peoples and their traditional rights, there have been sectoral legal regulations that have governed them. Sectoral legal regulations are, among others, the Law Number 5 of 1960 on Basic Agrarian Regulations; the Law Number 41 of 1999 on Forestry; the Law Number 39 of 1999 on Human Rights; the Law Number 32 of 2009 on Environmental Protection and Management; the Law Number 39 of 2014 on Plantations; the Law Number 6 of 2014 on Villages.

In the level of implementation regulations, there are several regulations governing indigenous peoples. They are, among others, the Regulation of the Minister of Agrarian Affairs of the Republic of Indonesia/Head of National Land Agency Number 5 of 1999 on Guidelines for Settlement of Communal Rights of the Indigenous Peoples, the Regulation of the Minister of Home Affairs of the Republic of Indonesia Number 52 of 2014 on Recognition and Protection of Indigenous Peoples, the Regulation of the Minister of Agrarian Affairs and Spatial Planning/Head of the Republic of Indonesia's National Land Agency Number 10 of 2016 on Procedures for Establishing Communal Rights in Land of Indigenous Peoples and Communities in Certain Areas, the Regulation of the Minister of Environment and Forestry of the Republic of Indonesia Number 34 of 2016 on Recognition and Protection of Local Wisdom in Natural Resource and Environment Management.

The Law Number 39 of 1999 on Human Rights emphasizes that in the framework of upholding human rights, the government and the people are obliged to protect indigenous peoples and their communal rights. ${ }^{12}$ In the forestry sector, the Law Number 41 of 1999 on Forestry provides the rights for indigenous peoples to collect forest products to fulfill their daily needs carry out forest management activities based on applicable communal law and obtain empowerment in order to improve their welfare. In addition, based on Forestry laws, indigenous peoples have

12 See the Law Number 39 of 1999 on Human Rights 
the right to communal forests that are distinguished from state forests. In the framework of providing legal protection for the existence of indigenous peoples, the Plantation Law threatens an authorized official who grants a plantation business permit over the indigenous peoples' communal rights with a 5-year imprisonment penalty.

The Constitution of the Republic of Indonesia states that state recognition of indigenous peoples and their traditional rights is conditional. To be recognized as an indigenous people the constitution requires the existence of these indigenous peoples to be still alive, in accordance with the development of the community, and in accordance with the principles of the Unitary State of the Republic of Indonesia. The Constitution requires that these three conditions be regulated in a separate law established in the context of carrying out the order of Article $18 \mathrm{~b}$ paragraph (2) of the Fourth Amendment of the 1945 Constitution. However, so far, the law referred to has not yet been promulgated.

In the absence of legal basis of the existence of indigenous peoples and their traditional rights within the framework of village governance, the Law Number 6 of 2014 on Villages provides an explanation regarding the requirements of the indigenous peoples. The indigenous people refer to people that the conditions for a shared feeling in the group (in-group feeling), indigenous government institutions, possessing indigenous assets, and having indigenous norms. The Village Law also provides an explanation regarding the conditions according to community development. According to the Village Law, the existence of indigenous peoples is considered in accordance with the development of the community if it meets the following requirements. First, the applicable Law recognizes its existence. Second, the community concerned and the wider community recognize its traditional rights. Third, its traditional rights do not conflict with human rights. The constitutional requirements state that the existence of indigenous peoples and their traditional rights must be in accordance with the principles of the Unitary State of the Republic of Indonesia. Therefore, the Law on Village explains that indigenous people and their traditional rights are in accordance with the principles of the Unitary State of the Republic of Indonesia. In addition, their existence does not threaten the sovereignty and integrity of the Unitary State of the Republic of Indonesia. Moreover, its indigenous norms are in accordance with applicable laws and regulations. If the indigenous community has become an Indigenous Village, ${ }^{13}$ then their authorities are ${ }^{14}$

1) regulation and implementation of government based on the original arrangement;

The Law Number 6 of 2014 on Village. Ibid. 
2) regulation and management of indigenous territories;

3) preservation of indigenous village socio-cultural values;

4) settlement of indigenous disputes based on communal law applied in the indigenous village in an area that is in accordance with the principles of human rights by prioritizing settlement by deliberation;

5) organizing a communal peace court hearing in accordance with the statutory legislation;

6) maintaining the peace and order of the indigenous village community based on communal law applied in the indigenous village; and

7) development of indigenous life in accordance with the socio-cultural conditions of the indigenous village community.

The current policy in the field of government regulation through Presidential Regulation of the Republic of Indonesia Number 49 of 2016 on the Management Agency is followed up by the land conversion of protected forest in Ajibata District, Toba Samosir Regency, for developing the Sibisa Lake Toba Tourism Area. The policy has disturbed the existence of the indigenous peoples of Batak Pardamean Sibisa, Raja Bius Motung, Ompu Ondol Butar-butar, and Raja Bius Naopat Sigapiton around Lake Toba. Government policies have led to disputes between the government and indigenous peoples. The Government and the indigenous peoples claim ownership of forest and communal land rights. The Government of the Republic of Indonesia claims formally that all areas of forest and land in the entire territory of Indonesia, that were formerly controlled by the Dutch East Indies Government, after Indonesia became independent as State Forest and State Land. The Government of the Republic of Indonesia claims that the communal forests and land controlled by indigenous people of Batak are illegal and do not have a strong legal basis. While indigenous peoples claim that they have existed since the days when Indonesia was not yet independent. The indigenous peoples argue that the boundary pillars containing ancestral frameworks are evidence of their hereditary existence. The indigenous peoples also argue that their existence is protected by the Constitution of the Republic of Indonesia. In addition, their existence is also supported by the Law Number 5 of 1960 on Basic Agrarian Regulations, the Law Number 41 of 1999 on Forestry, the Law Number 39 of 1999 on Human Rights, the Law Number 32 of 2009 on Environmental Protection and Management, the Law Number 39 of 2014 on Plantations, and the Law Number 6 of 2014 on Villages.

To respond the claims of the indigenous peoples, the Government of the Republic of Indonesia adheres strictly to the Principle of the State's Rule of Rights as stipulated in Article 33 Paragraph (3) of the 1945 Constitution. It reads "The land, water, and natural resources contained therein are controlled by the State and used for the greatest prosperity of the people". The government strongly believes that the claim to the forests and land in Ajibata District that is currently 
physically controlled by the indigenous peoples is legal and in accordance with the applicable constitution and legislation. With this belief, the government seeks to continue the development of the Lake Toba Sibisa Tourism Area on the communal forest and land of the indigenous peoples, and as a form of compromise, the government will provide appropriate compensation, the amount of which is determined by the government through a consensus agreement with the members of the related indigenous peoples.

Regarding land ownership disputes between the Government of the Republic of Indonesia and the indigenous peoples around Lake Toba, it is necessary to study and examine government policies in resolving these problems. Ideally, the government should not ignore Article 18b paragraph (2) of the Fourth Amendment of the 1945 Constitution and several laws and regulations that provide legal protection for the existence of indigenous peoples and their traditional rights. Even though the United Nations Declaration on Human Rights of Indigenous Peoples' (UNDHRIP) binding power does not originate from itself, the Indonesian government as a participating country must not neglect the rights and obligations of states as regulated. The Declaration recognizes the rights of indigenous peoples to their land, and indigenous peoples have access to resolve disputes with the government where the government must communal law and traditions that they believe in. ${ }^{15}$ The Indonesian government must wisely pay attention to the fact that communal land is a cultural identity for indigenous peoples. For indigenous peoples, their relationship with their land is not only a matter of ownership but also a spiritual element for preserving cultural heritage for future generations. ${ }^{16}$ Land is the basis of life and culture of indigenous peoples throughout the world. Without respect for their lands, the existence of indigenous peoples will be threatened. ${ }^{17}$

In connection with the spatial plan, the development of the Lake Toba Sibisa Tourism Area must not ignore the existence of the Presidential Regulation Number 81 of 2014 on the Spatial Planning of Lake Toba Area. One direction of spatial planning policy based on the Presidential Regulation is "preservation of the village area and the culture of the indigenous people of Batak." With a strategy of "maintaining the existence and revitalization of the Batak traditional village area

\footnotetext{
15 Brendan M Tobin, "Bridging the Nagoya Compliance GAP: The Fundamental Role of Customary Law in Protection of Indigenous Peoples Resources and Knowledge Rights," Law and Environmental Development Journal, Vol. 9, No. 2, 2013, p. 148.

16 Gilbert J., Indigenous Peoples' Land Rights under International Law: From Victims to Actors, New York: Transnational Publishers, 2006.

17 UNPFII dalam Jeremie Gilbert, Custodians and the Land: Indigenous Peopleas, Human Rights and Cultural Integrity, London: University of Roehamton, 2009, p. 1.
} 
..."18 If the government pays attention to these provisions, the government should not be able to take policies that have an impact on endangering the indigenous peoples of Batak around the Lake Toba area. Spatial use policies that affect the disruption of the existence of indigenous peoples of Batak and their traditional rights are not only contrary to the Constitution of the Republic of Indonesia, they are also in conflict with the Human Rights Law, Forestry Law, Village Law, and contrary to Presidential Regulation on Lake Toba Space Area. Therefore, this particular policy will potentially undergo a judicial review and/or charged by the State Administrative Court.

The plan to develop Sibisa Lake Toba Tourism Area has disturbed the existence of the indigenous peoples of Batak in the Ajibata District, Toba Samosir Regency. The indigenous peoples of Raja Bius Motung (1,800 people) claim that their community has existed in the land of Motung since more than 400 years ago (at least 15 generations). The indigenous peoples of Raja Bius Motung control approximately 100 hectares of the "Harangan" (prohibited forest) communal forest that is guarded and conserved together as a spring. In addition to the "Harangan" forest, they also controlled the "Dolok Motung Field" (Motung ulayat land) covering an area of approximately 200 hectares. The Dolok Motung Field is designated as a place for cattle release (grazing). The indigenous peoples of Raja Bius Motung also control the public land of the "Haporusan" (burial) area of approximately 10 hectares; Reservoir, Sekdam, and Bondar or Juma Gala-Gala and Bonda Bolon water ropes for approximately 12 KM; Pangokkalan Hirik (shared fields) covering 50 hectares. ${ }^{19}$

In the prohibited forest of the indigenous peoples of Raja Bius Motung, there applies prohibition or restrictions. No one should cut and take wood from the prohibited forest. No one should wear red-colored clothing on the prohibited forest. No one should take greedily from a spring in the prohibited forest. Violators of the prohibition will be subject to a fine from Raja Bius. Based on the statement of the Motung Village Head and several members of the indigenous peoples of Motung in an interview with the author, someone who tried to fetch water improperly from a spring in the prohibited forest was found dead. It is believed by the people of Motung Village that the person fetched the water from the prohibited forest spring to sell the water. In the above case, the curse of death is part of the traditional sanctions imposed on violators of the communal restrictions on Raja Bius. ${ }^{20}$

The indigenous people of Raja Bius Motung have a territory with boundaries marked by the existence of monuments in which the ancestors' frameworks are

\footnotetext{
18 See Presidential Regulation of the Republic of Indonesia Number 81 of 2014 on Spatial Planning of Lake Toba Area

19 Sabar Manurung, dkk., "Aspirasi dn Tutuntutan Raja Bius Motung 4 Marga Sebius/ Sekawanan Motung Manurung, Sitorus, Sirait, Ambarita Kec. Ajibata, Kab. Toba Samosir, Tuntutan, Tobasa, 2018, pp. 1-2.

20 Information obtained from an interview between the author and the village head with members of the indigenous peoples in Ajibata District, Toba Samosir Regency, North Sumatra Province.
} 
stored. The monuments they built became a sign of territorial boundaries as well as proving the existence of their ancestors and evidence of territorial mastery by the ancestors. The construction of the monuments by the indigenous peoples of Motung is intended to be a guideline in determining the boundary of their authority over the territory. Guided by the boundary monument, they can know the territorial boundaries easily, and with full confidence.

The indigenous peoples of Raja Naopat Sigapiton (446 inhabitants) have rice fields called "golat" consisting of the Ganjang Golat belonging to the Nadapdap clan, the Butar Golat belonging to the Butarbutar clan, the Sibuntuon Golat belonging to the Manurung clan, and the Sosor Golat belonging to Sirait clan. The ancestors of the indigenous people of the Bius Raja Naopat came from Sibisa Village, and today they are the 8th generation (around 250 years ago). In addition to the Golat, the indigenous people of Bius Raja Naopat have parhuta (settlements), polak (fields), tombak (communal forest), adaran (cattle grazing). ${ }^{21}$

The indigenous peoples of Pomparan Ompu Ondol Butar-butar of Sileang-leang Hamlet, claims to be a descendant of Ompu Ondol Butar-butar, who has controlled a communal land covering 120 hectares since before Indonesia's independence. They claim that the existence of sacred tombs of their ancestors as evidence of the existence of the indigenous peoples of Pomparan Ompu Ondol Butar-butar. Like other indigenous peoples of Batak, the indigenous peoples of Pomparan Ompu Ondol Butar-butar also follow similar communal law in the field of marriage and inheritance, which they hold firm to this day. They still feel bound and revere to the communal law as a guide to their lives, and comply with all the communal restrictions.

Indonesia as a participant country of the United Nations Declaration on the Human Rights of Indigenous People (UNDHRIP) must respect and adhere to the principles of protection of the indigenous peoples in the country. Tied to UNDHRIP, Indonesia should position indigenous peoples as equals and respect their culture, law, land, territory, and natural resources. Indigenous peoples have the right to determine their own destiny, are free to determine their political status, have the right to participate in economic development, and they have the right to organize autonomously their own government on a local scale. ${ }^{22}$

\section{Protection of Communal Land}

As a common problem of indigenous peoples in the world, although the world through the Declaration of the Rights of Indigenous Peoples Number 1 of 2007 has accommodated the aspirations of the rights of indigenous peoples, their claim to

\footnotetext{
21 Sauth Nadapdap, dkk., "Patotahon (Pengukuhan) Kepemilikan dan Pengelolaan Tano dan Tombak Adat," Surat, Tobasa, 2018, pp. 1-2.

22 Article 5 United Nation Declaration on Human Right of Indigenous People.
} 
land as ancestral heritage often faces government policies. This issue becomes important because land, to indigenous peoples, is an inseparable part of their culture, and land is a differentiator of the existence of indigenous peoples with other indigenous peoples. ${ }^{23}$ Indigenous peoples in the world, in general, are often at the bottom of the social and economic ladder of where they live. In this regard, in general, in addition to claiming shelter, health, and food, they also claim that their culture, their language, and their land are endangered. ${ }^{24}$

The dispute between the Indonesian Government and the indigenous peoples of Batak around the Lake Toba area in the Ajibata District emerged as excess of government policy that claimed the indigenous peoples' land as state land. Through its claim, the government wants to utilize the indigenous peoples' land as one of the locations for facilities and infrastructure to be built in order to support the development of the Sibisa Lake Toba Tourism Area. In submitting its claim, the government bases itself on Article 33 Paragraph (3) of the Fourth Amendment of the 1945 Constitution and the Law of the Republic of Indonesia Number 5 of 1960 on Basic Agrarian Regulations. ${ }^{25}$

Article 33 Paragraph (3) of the Fourth Amendment of the 1945 Constitution states that "The land, water, and natural resources contained therein are controlled by the State and used for the greatest prosperity of the people". In the Indonesian land legal system, these provisions become the constitutional basis for the application of the Principle "Right to Control the State". Grammatically, Article 33 Paragraph (3) of the Fourth Amendment of the 1945 Constitution affirms the constitutional basis that the state controls all forms of natural wealth including forests, land, soil and natural resources contained therein which are on the whole territory of the Unitary State Republic of Indonesia. As a derivative, the Law of the Republic of Indonesia Number 5 of 1960 also describes the right to rule the state as the right that applies to all land in the entire territory of the Republic of Indonesia upon rights to land either controlled or not controlled by people. ${ }^{26}$

In the concept of the right to control the country, the state has the authority to formulate policies, plan, make regulations, conduct management, and conduct supervision. The state has the authority to regulate and administer land use, inventory, and maintenance. The state has the authority to determine and regulate legal relations between people and land. In the conception of rights over the state,

$23 \quad$ Siegfried Wiesner, "The Cultural Rights of Indigenous Peoples: Achievments and Continuing Challenges," The European Journal of International Law, Vol. 22, No. 1, 2011, p. 1. See also Katja Gocke, Protection and Realization of Indigenous Peoples Land Rights at the National and International Level, "Protection and Realization of Indigenous Peoples' Land Rights," Goettingen Journal of International Law, Vol. 5, Issue 1, 2013, p. 1.

24 Reismen, "International Law and the Inner Worlds of Others," 9 St Thomas Law Review, 1996, p. 25.

25 See the Law of the Republic of Indonesia Number 5 of 1960 on Basic Agrarian Regulations.

26 Myrna A. Safitri, "Hak Menguasai Negara Di Kawasan Hutan: Beberapa Indikator Menilai Pelaksanaannya," Jurnal Hukum Lingkungan Indonesia, Vol. 1, Issue 2, December 2014, p. 8. 
the state has the authority to regulate legal relations between people and legal actions related to land. ${ }^{27}$

Based on the authority derived from the state's right to control, the state can take the following actions. ${ }^{28}$

1. Make a general plan regarding the supply, designation, and use of land;

2. Determine the existence of various types of land rights;

3. Strive to have as many people as possible to have relation to the land;

4. Determine that every person, both individual and legal entity who has land rights, makes an effort on the land they own;

5. Strive for no abandoned land;

6. Regulate legal relations between people and legal actions with the land;

7. Regulates matters regarding land clearing, collection of forest products, water use, and air space;

8. Regulates the taking of natural resources contained in land;

9. Conduct land registration.

However, the conception of rights over the state must not be interpreted in such a way that the authoritarian actions of the state on land can be justified. That is because along with the state's inherent right to control the state, there is also an obligation to implement the right to control the state in an effort to achieve the greatest prosperity of all the people of Indonesia (including the welfare of the indigenous peoples). The right to rule the country and the prosperity of the people is like two sides attached to the same time, place, and situation. Article 2 paragraph (3) of the Law of the Republic of Indonesia Number 5 of 1960 states that the authority derived from the right to control the state is used to achieve the greatest prosperity of the people in the sense of nationality, welfare, and independence in the society and the State of Law of Indonesia which is independent, sovereign, fair, and prosperous.

In addition to recognizing the right to rule the state, the Law of the Republic of Indonesia Number 5 of 1960 on Basic Agrarian Regulations also recognizes the existence of indigenous peoples' rights over communal land. Some of the articles on which the indigenous peoples' communal land is recognized are Article 2 paragraph (4), Article 3 and Article 5. Based on these regulations, communal land as an embodiment of communal rights is recognized in Indonesia. Conceptually, communal rights are defined as rights that are born due to intensive and

\footnotetext{
See the Law of the Republic of Indonesia Number 5 of 1960 on Basic Agrarian Regulations.

See Soetiknjo in Ida Nurlinda, Prinsip-prinsip Pembaruan Agraria Perspektif Hukum, Jakarta: Rajawali Pers, 2009, pp. 59-60.
} 
continuous exploitation of a piece of vacant land, ${ }^{29}$ or the inherent right as a specific competency inherent in the indigenous peoples in the form of authority or power to administer and regulate the communal land with the power to apply both inward and outward..$^{30}$ Outwardly and inwardly means that the communal land, as an embodiment of the communal rights of the indigenous peoples, regulates how land can be divided for various needs of members of the indigenous peoples, including distribution for the common good. The meaning of power applies to the outside means that communal land is maintained and protected from interference of strangers. ${ }^{31}$

In the conception of communal rights, indigenous peoples have the following authorities over their communal land..$^{32}$

1. Arranging and organizing the use of land (for settlements, farming, etc.) stock (making new settlements/rice fields, etc.) and soil maintenance;

2. Regulate and determine legal relations between people and land (giving certain rights to certain subjects);

3. Arranging and establishing legal relations between people and legal actions relating to land (buying and selling, inheritance, etc.).

Regarding the discussion of state control rights and communal land rights, it appears that both have the same strong legal foundation. The right to control the state is based on the Constitution of the Republic of Indonesia Article 33 paragraph (3) and Article 2 of the Law of the Republic of Indonesia Number 5 of 1960. On the other hand, the communal land rights are also based on the Constitution of the Republic of Indonesia, namely Article 18b and Article 2, 3, and 5 of the Law Republic of Indonesia Number 5 of 1960. This shows that both of them have the same strong legal foundation. Therefore, their existences are equally strong. Therefore, the two do not override each other and do not become priorities. Moreover, the right to control the country actually originates from the concept of communal law, which always occupies the public interest above personal and group interests. The implementation of state control rights and communal land rights must be synergistic, harmonious, synchronous, and inseparable. ${ }^{33}$ The implementation of the right to control the state must always respect the existence of communal land rights and the implementation of communal land rights as an

29 Achmad Sodiki dalam Muazzin, "Hak Masyarakat Adat (indigenous peoples) atas Sumber Daya Alam: Perspektif Hukum Internasional," Padjadjaran Jurnal IImu Hukum, Vol. 1 No. 2, August 2014, p. 329.

30 See Maria S.W. Sumardjono in Djamanat Samosir, "Legalisasi Hak Ulayat Masyarakat Hukum Adat," Jurnal Masalah Masalah Hukum, Jilid 42, No. 2 April 2013, p. 238.

31 See Winahyu Erwiningsih, "Mencari Tolok Ukur Eksistensi Hak Ulayat atas Tanah Menurut UUD 1945," Jurnal Hukum, Vol. 10, No. 22, January 2003, p. 78.

$32 \mathrm{Hj}$. Rosmidah, "Pengakuan Hukum Terhadap Hak Ulayat Masyarakat Hukum Adat dan Hambatan Implementasinya," Jurnal Hukum Universitas Jambi, Vol. 2, No. 4, 2010, p. 5.

33 See Kusumadara dalam Afifah Kusumadara, "Perkembangan Hak Negara Atas Tanah: Hak Menguasai atau Hak Memiliki?" Jurnal Media Hukum, Vol. 20, No. 2, 2013, p. 2. 
embodiment of the communal rights of the indigenous peoples must not neglect the existence of the right to control the state.

\section{E. Solutions and Middle Grounds}

It is undeniable that the development of the Sibisa Lake Toba Tourism Area is a national development program that is believed to be able to improve the welfare of the people and will be able to overcome the country's foreign exchange problems. Additionally, the Government of the Republic of Indonesia has a strong legal basis to implement the right to control the state in fulfilling the obligation to realize national welfare.

In this regard, the author does not want to position himself as anti-government policies related to tourism development, because the author is aware of the fact that the government has a strong legal position. The author only puts the effort to see that tourism development does not result in negative excesses on the environment. In the Presidential Regulation Number 81 of 2014 on the Spatial Planning of Lake Toba Area, Ajibata District is included in the protected zone that protects the subordinating areas. Referring to these provisions, the government's policy to determine the location of the Sibisa Lake Toba Tourism Area development is inappropriate. The risk of environmental damage is very high if tourism facilities such as hotels, resorts, hypermarkets, souvenir shopping centers, training centers, and golf courses will be built in the protected zone. The site selection policy for the construction of tourism facilities in the protected zone violates the principle of spatial use in accordance with its function and designation. Ideally, the construction site for tourism facilities should not be assigned to a protected zone.

If the government imposes its policy to develop tourism facilities in the protected zone, the government must seriously commit to implementing the principle of spatial use with minimal tolerance, where technical and vegetation engineering must be carried out. The built-up space must not exceed $20 \%$ of the occupied land. An area covering $80 \%$ of the land must be allocated to support the protected zone. The building of tourism facilities such as hotels, resorts, training centers, souvenir shopping centers, golf infrastructure, and other spaces should not be made of concrete construction, but it must be engineered in such a way as to adapt to the nature of the space, such as the "bolon" house on stilts typical of the indigenous peoples of Batak. By conducting technical and vegetation engineering, the risk of damage to the environment and space can be minimized.

The dispute over the right to control the state with the rights of indigenous peoples, principally, can be resolved without having to sacrifice Siberia Lake Toba Tourism Area development policies. In order for the government policy to not harm the rights of indigenous peoples, the government must seriously implement the principles of protection of indigenous peoples as has become the UNDHRIP 
standard. ${ }^{34}$ In principle, the Indonesian government must not relocate the existence of indigenous peoples. The government must appoint them as partners of development by listening to and accommodating their aspirations. ${ }^{35}$ The government is expected to open up in negotiation and propose to the indigenous peoples the formulation of the agreement as follows.

1. The Government, with the best effort, protect the existence of indigenous people in their place of residence;

2. The government helps and finances the renovation of communal houses so that they function as bolon traditional houses as in accordance with the values of the indigenous peoples of Batak, thus supporting the traditional tourism zone;

3. The government provides appropriate compensation for the agricultural communal land affected by the development project;

4. The government promises to provide a CSR zone for the homestay business location for indigenous peoples in the form of usage rights;

5. Within the CSR framework, the government promises to educate, train, foster, prepare, and provide capital assistance for indigenous peoples to manage homestay businesses in a sustainable manner;

6. Within the CSR framework, the government promises to accommodate and help indigenous peoples who want to survive as field farmers.

The formulation of the agreement between the government and the indigenous peoples above is a win-win solution for the conflicting rights of the state to oppose the constitutional rights of indigenous peoples. Indigenous peoples, as Indonesian citizens, are constitutionally obliged to support national development programs that concern the public interest. As Indonesian citizens, indigenous peoples must uphold the Pancasila Ideology, especially the third principle: the unity of Indonesia. ${ }^{36}$ In the strategic interest of the nation and state, indigenous peoples must implement a patriotic attitude "willing to sacrifice for the sake of the state". On the other hand, the government as an embodiment of the state must respect the rights of indigenous peoples as protected by the Constitution of the Republic of Indonesia, the Law of the Republic of Indonesia on Human Rights, and UNDHRIP. The government must not relocate, the government must provide compensation money for the indigenous peoples' agricultural fields that are built and the government must invite the community as partners in the Lake Toba Tourism Area Development program.

\footnotetext{
34 See Barelli, "The Role of Soft Law in The Internastional Legal System: The Case of the United Nations Declaration on the Rights of Indigenous Peoples," International \& Comparative Law Quarterly, Vol. 58, 2009, p. 957.

35 United Nation Human Rights, “Indigenous Peoples and the United Nations Human Rights System," New York: United Nations, 2013, pp. 1-4.

36 The third principle of Pancasila.
} 


\section{F. Conclusion}

The policy of the land conversion of communal forest and land by the Indonesian Government for the development of the Sibisa Lake Toba Tourism Area is not in accordance with the relevant laws and regulations. The regulations that have been violated include Article 18b of the 1945 Constitution, Article 15 of the Law Number 32 of 2009 on Environmental Protection and Management, Presidential Regulation Number 81 of 2014 on Spatial Planning of Lake Toba Area, the Law Number 39 of 1999 on Human Rights, and the Law Number 6 of 2016 on Village Governance. They are contrary to the United Nations Declaration on Human Rights of Indigenous Peoples (UNDHRIP).

If the government intends to impose its policies, the government must implement engineering and vegetation in the development of tourism facilities and infrastructure, and the government must implement the principle of spatial use with minimal tolerance, where space is only allowed to be $20 \%$ wide, while the remaining $80 \%$ is designated as a protected. The ideal solution to the land dispute between the Indonesian Government and the indigenous peoples is that the Indonesian government must implement Article 18b of the 1945 Constitution, Articles 3 and 5 of the Basic Agrarian Regulations, UNDHRIP, and the Presidential Regulation Number 81 of 2014 on the Spatial Planning of Lake Toba Area. The Indonesian government must not relocate settlements, must pay compensation, and must position the indigenous and tribal peoples as partners in the development of the Lake Toba tourism area through CSR programs.

\section{References}

\section{Books}

Gilbert Jeremie, Indigenous Peoples' Land Rights under International Law: From Victims to Actors, Transnational Publishers, New-York, 2006.

Custodians and the Land: Indigenous Peoples, Human Rights, and Cultural Integrity, University of Roehampton, London, 2009.

Ida Nurlinda, Prinsip-Prinsip Pembaruan Agraria Perspektif Hukum, Rajawali Pers, Jakarta, 2009.

Imamulhadi, Penegakan Hukum Lingkungan Berbasis Kearifan Masyarakat Adat Nusantara, Unpad Press, Bandung, 2011.

\section{Other Documents}

Amdal Pembangunan Kawasan Pariwisata SIBISA.

Barelli, Mauro, "The Role of Soft Law in The International Legal System: The Case of the United Nations Declaration on the Rights of Indigenous Peoples," International \& Comparative Law Quarterly, Vol. 58, 2009. 
Efendi Pane dan Tim, "Laporan Peninjauan Lapangan Identifikasi dan Inventarisasi Permasalahan Tenurial Kawasan Hutan Rencana Lokasi Badan Otorita Pengelola Kawasan Pariwisata Danau Toba Seluas 500 Hektar di Kecamatan Ajibata Kabupaten Toba Samosir Sumatera Utara", Kajian, Dinas Kehutanan Provinsi Sumatera Utara, Medan, 2016.

Djamanat Samosir, "Legalisasi Hak Ulayat Masyarakat Hukum Adat," Jurnal Masalah Masalah Hukum, Jilid 42, No. 2, 2013.

Flysh Geosh, "Mengenal Jenis Jenis Tanah di Indonesia: Latosol, Regosol, dan Andosol", https://www.geologinesia.com/2017/07/mengenal-jenis-jenis-tanahdi-indonesia.html, accessed on November 2018.

Hj. Rosmidah, "Pengakuan Hukum Terhadap Hak Ulayat Masyarakat Hukum Adat dan Hambatan Implementasinya," Jurnal Hukum Universitas Jambi, Vol. 2, No. 4, 2010.

Gocke, Katja, "Protection and Realization of Indigenous Peoples Land Rights at the National and International Level: Protection and Realization of Indigenous Peoples' Land Rights," Goettingen Journal of International Law Vol. 5, Issue 1, 2013.

Kusumadara dalam Afifah Kusumadara, "Perkembangan Hak Negara Atas Tanah: Hak Menguasai atau Hak Memiliki?" Jurnal Media Hukum, Vol. 20, No. 2, 2013.

Myrna A. Safitri, "Hak Menguasai Negara Di Kawasan Hutan: Beberapa Indikator Menilai Pelaksanaannya," Jurnal Hukum Lingkungan Indonesia, Vol. 1, Issue 2, 2014.

Muazzin, "Hak Masyarakat Adat (Indigenous Peoples) atas Sumber Daya Alam: Perspektif Hukum Internasional", Padjadjaran Jurnal IImu Hukum, Vol. 1, No. 2, 2014.

Reismen, "International Law and the Inner Worlds of Others," 9 St Thomas Law Review, 1996.

Sabar Manurung, dkk., "Aspirasi dan Tuntutan Raja Bius Motung 4 Marga Sebius/Sekawanan Motung Manurung, Sitorus, Sirait, Ambarita Kec. Ajibata, Kab. Toba Samosir, Tuntutan, Tobasa, 2018.

Sauth Nadapdap, dkk., "Patotahon (Pengukuhan) Kepmilikan dan Pengelolaan Tano dan Tombak Adat," Surat, Tobasa, 2018.

Tobin, Brendan M. "Bridging the Nagoya Compliance GAP: The Fundamental Role of Customary Law in Protection of Indigenous Peoples Resources and Knowledge Rights," Law and Environmental Development Journal, Vol. 9, No. 2, 2013.

Wiesner, Siegfried, "The Cultural Rights of Indigenous Peoples: Achievements and Continuing Challenges," The European Journal of International Law, Vol. 22, No. 1, 2011.

Winahyu Erwiningsih, "Mencari Tolok Ukur Eksistensi Hak Ulayat atas Tanah Menurut UUD 1945," Jurnal Hukum, Vol. 10, No. 22, 2003. 


\section{Legal Documents}

Inter American Court of Human Rights, 2001.

Presidential Regulation of the Republic of Indonesia Number 81 of 2014 on the Spatial Planning of Lake Toba Area.

Presidential Regulation of the Republic of Indonesia Number 49 of 2016 on Lake

Toba Area Management Authority Agency,

Regulation of the Minister of Agrarian Affairs of the Republic of Indonesia/Head of National Land Agency Number 5 of 1999 on Guidelines for Settlement of Communal Rights of the Indigenous Peoples.

Regulation of the Minister of Home Affairs of the Republic of Indonesia Number 52 of 2014 on Recognition and Protection of Indigenous Peoples.

Regulation of the Minister of Agrarian Affairs and Spatial Planning/Head of the

Republic of Indonesia's National Land Agency Number 10 of 2016 on Procedures for Establishing Communal Rights in Land of Indigenous Peoples and Communities in Certain Areas.

Regulation of the Minister of Environment and Forestry of the Republic of Indonesia Number 34 of 2016 on Recognition and Protection of Local Wisdom in Natural Resource and Environment Management.

United Nations Declaration on Human Rights of Indigenous Peoples.

United Nations Human Rights, "Indigenous Peoples and the United Nations Human

Rights System," United Nations, New York, 2013.

The Fourth Amendment of the 1945 Constitution.

The Law of the Republic of Indonesia Number 5 of 1960 on Basic Agrarian Regulations.

The Law of the Republic of Indonesia Number 39 of 1999 on Human Rights.

The Law of the Republic of Indonesia Number 41 of 1999 on Forestry.

The Law of the Republic of Indonesia Number 26 of 2007 on Spatial Planning.

The Law of the Republic of Indonesia Number 32 of 2009 on Environmental Protection and Management.

The Law of the Republic of Indonesia Number 6 of 2014 on Villages.

The Law of the Republic of Indonesia Number 39 of 2014 on Plantations. 